\title{
MOLINEUS TORULOSUS \\ (Nematoda, Trichostrongylina, Molineoidea) \\ A PARASITE OF NEOTROPICAL PRIMATES: NEW MORPHOLOGICAL AND HISTOLOGICAL DATA
}

\author{
DURETTE-DESSET M.-C.*, FRIBOURG BLANC L.A.* \& VUONG P.N.**
}

\begin{abstract}
Summary :
Molineus torulosus (Molin, 1861) parasite of Cebus spp. from South America is redescribed in Cebus apella and C. olivecaeus (new host) from French Guyana with emphasis on the synlophe. During the maturation process, the larvae dwelt in the cysts carved alongside the external part of the small intestine. The turn-out of the mature worms and the laid eggs depended on the tissular organisation of cyst walls as the inflammatory process waned and fibrosis progressed to seal the cystic lumen. Adult worms entwine themselves in the cysts, live there permanently as their presence has never been evidenced in the intestinal lumen. They copulated, laid eggs, degenerated and died once entrapped by the fibrotic process. Laid eggs released in the intestinal lumen through a narrow channel ensured the continuation of the developmental cycle. However, erratic migration was possible via the vascular channels surrounding the cysts.
\end{abstract}

KEY WORDS : Molineus torulosus (Molin, 1861), Nematoda, Trichostrongylina, Molineoidea, Neotropical primates, histology

\section{INTRODUCTION}

T The genus Molineus Cameron, 1923, is widespread throughout the World (except Australia) in the Carnivora and Neotropical primates. Among the four species described in these hosts, Molineus torulosus (Molin, 1861), a parasite of Cebus spp. (Cebidae) is the only one whose site is very particular. The adult worms dwell in nodular formations, developed alongside the external wall of the small intestine. These nodules communicate with the intestinal lumen through a channel. The histological aspect of these structures has been studied by several authors (Mazza \& Parodi, 1930; Brack, Myers \& Kunz, 1973; Rego \& Schäeffer, 1987). However, the morphological

* Laboratoire de Biologie Parasitaire, Protistologie, Helminthologie, IFR 63, CNRS, Muséum national d'Histoire naturelle, 61, rue Buffon, F-75231 Paris cedex 05.

** Unité d'Anatomie et de Cytologie Pathologiques, Hôpital StMichel, 33, rue Olivier de Serres, F-75730 Paris cedex 15.

Correspondence : M.-C. Durette-Desset.

Fax : 1 (33) 40793899.

E-mail : mcdd@cimrs1.mnhn. fr
Résumé : MOLINEUS TORULOSUS (NEMATODA, TRICHOSTRONGYLINA, Molineoidea) parastte de Primates nÉotropicauX : NOUVElles DONNÉES MORPHOLOGIQUES ET BIOLOGIQUES

Molineus torulosus Molin, 1861 ) parasite de Cebus spp. en Amérique du Sud est redécrit chez Cebus apella et chez C. olivecaeus (nouvel hôte) en Guyane française en particulier sur les caractères du synlophe et ceux de la femelle qui n'étaient pas connus. Lors de la maturation, les larves résident dans des kystes creusés le long de la partie externe de la paroi intestinale. Le devenir des Vers matures et des oeufs dépend de l'organisation tissulaire de la paroi kystique dont la détersion du processsus inflammatoire est suivie par une fibrose cicatricielle qui tend à colmater la lumière kystique. Les Vers adultes s'enferment dans les kystes, y vivent de façon permanente puisque leur présence n'a jamais été démontrée dans la lumière intestinale. Ils s'accouplent, pondent des oeufs, dégénèrent et meurent une fois englobés dans le tissu fibreux. Les ceuts pondus, largués dans la lumière intestinale par un pertuis, assurent la continuité du cycle.

MOTS CLÉS : Molineus torulosus Molin, 18611, Nematoda, Trichostrongylina, Molineoidea, Primates néotropicaux, histologie.

data concerning this species have not been thoroughly investigated.

During a mission in French Guyana (July-August 1992) in the hunting grounds of the Wayãpi Indians, one of the authors (L.A.F.B.) was able to examine the small intestines of some monkeys and to collect new material.

The aim of this work is to redescribe Molineus torulosus with new data (particularly the synlophe) and compare the histological findings with those already reported by other authors.

\section{MATERIAL AND METHODS}

\section{MATERIAL}

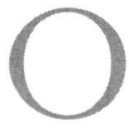
ut of six Cebus apella L., 1758, caught between 12 July and 7 August 1992, five were adults and parasitized by nematodes; only the young one was negative. One Cebus olivaceus Schumburg, 1848 , caught on 20 July was also parasitized by nematodes. 


\section{MORPHOLOGICAL STUDY}

All of these monkeys were dissected. In this paper we study only the Trichostrongyles that dwelt in cysts developed alongside the duodenum and the jejunum. Three cysts were opened and the nematodes collected and stored in $70 \%$ ethanol. Nematodes were studied in temporary wet mounts in water and, when necessary, cleared in lactophenol. Measurements of 10 males and 10 females are given in micrometres except where otherwise stated. The nomenclature used above the family-group is that of Durette-Desset \& Chabaud (1995). The synlophe was studied following the method of Durette-Desset (1985), and the nomenclature used for the study of the caudal bursa is that of Durette-Desset \& Chabaud (1981). Voucher specimens were deposited in the Helminthological Collections of the Muséum national d'Histoire naturelle, Paris, France (MNHN).

The nomenclature concerning the hosts follows Wilson \& Reeder, 1993.

\section{HisTOLOGICAL STUDY}

Samples of intestine harboring cysts were fixed in $10 \%$ formalin, processed for paraffin. Histological sections, five micrometres thick, were stained with Haematoxylin-Eosin-Saffron.

\section{RESULTS}

\section{Morphology of Molineus tORULOSUS (Molin, 1861)}

Studied material: 12 males, 12 females, MNHN 475 KQ extracted from one cyst.

Host: Cebus apella L., 1758 (Cebidae, Primates).

Site: one cyst located in the anterior part of the jejunum. Geographical origin: French Guyana (Camopi), 7 august 1992.

\section{Redescription}

Nematodes with body uncoiled. Presence of circular excretory furrow, not surrounded by cuticular expansions (Fig. 2 A, C). Excretory pore situated at same level as furrow, deirids situated posterior to furrow (Fig. 2 C).

Head: Cephalic vesicle present. In apical view, rounded buccal opening surrounded by two small amphids, six externo lateral papillae and four cephalic papillae (Fig. 2 B).

Synlophe: (studied in one male and two females). In both sexes, cuticle bears uninterrupted ridges. Dorsal ridges and lateral ridges appearing posterior to cephalic vesicle (Fig. $1 \mathrm{~A}$ ), ventral ridges just posterior to excre- tory pore (Fig. 1B) Ridges disappearing just anterior to caudal bursa in male and at caudal extremity in female (Fig. 2L).

Number of ridges varying along body. In both sexes, number increasing from seven (three dorsal, four lateral) posterior to cephalic vesicle (Fig. 1A) to 12 (five dorsal, four lateral, three ventral) at level of deirids (Fig. 1B) to 14 (five dorsal, four lateral, five ventral) at level of oesophago-intestinal junction. (Fig. 1C). In male, this number remaining constant along first third of body (Fig. 1D). Then, number of ridges reaching 16 (six dorsal, four lateral, six ventral) at mid-body (Fig. 1E) and remaining constant until level of caudal bursa (Fig. 1F). In female, posterior to level of oesophago-intestinal junction, (Fig. 1G), number of ridges varying according to the level between 18 (seven dorsal, seven ventral, four lateral) within first third to 14 (five dorsal, five ventral, four lateral) at mid-body (Fig. 1H). Between mid-body to vulva level, number varying between 16 (five dorsal, seven ventral, four lateral) to 17 with an extra dorsal ridge.

Ridges regularly spaced except those opposite lateral fields which are close to one another. Ridges orientated perpendicularly to body surface (Fig. 1A-H).

Males: 8.9 (7.9- 9.7) $\mathrm{mm}$ long and 168 (145-187) wide at mid-body; cephalic vesicle $44(40-48)$ long by 56 (5265) wide; nerve ring, excretory pore and deirids situated at 214 (185-240), 256 (230-285) and 287 (260305) from apex, respectively; oesophagus 532 (460-595) long (Fig. 2A).

Symmetrical caudal bursa with pattern of type 2-1-2, not spiny on lateral lobes (Fig. 2H). Rays 4 short with extremities at about same distance as between those of rays 3 and rays 5. Rays 8 arising from proximal third of dorsal ray, shorter than latter. Dorsal ray divided into two branches at its distal extremity, each giving rise to three small branches, firstly external branches (rays 9) then phasmids and rays 10 (internal branches).

Spicules alate, 178 (172-180) long, with handle sligthly shorter than blade. Blade divided first into three branches: one externo lateral branch and two internal branches. The externo-lateral branch is thickest and longest. The three branches sharp and inclused in membrane (Fig. 2D-F). Cone genital very discret with two small papillae 7. Papilla zero not observed. Gubernaculum rectangular in shape in ventral view, sligthly curved in lateral view with proximal hook, 111 (108115) long and 10 wide (Fig. 2I-K).

Females: 11.6 (10.0-12.3) mm long and 167 (140-195) wide at mid-body; cephalic vesicle 44 (40-45) long by 57 (50-65) wide; nerve ring, excretory pore and deirids situated at 208 (185-250), 251 (235-290), 293 (275340) from apex, respectively; oesophagus 545 (460-630) long. 



Fig. 1. - Molineus torulosus (Molin, 1861) in Cebus apella. Synlophe. A-F, Male $8.5 \mathrm{~mm}$ long. A, at excretory pore level. B, at left deirid level. C, at oesophhago-intestinal junction. D, at $3.2 \mathrm{~mm}$ from head. E, at mid-body. F, at $1.2 \mathrm{~mm}$ above caudal bursa. G, H, Female $11.7 \mathrm{~mm}$ long. $\mathrm{G}$, at oesophago-intestinal junction. $\mathrm{H}$, at mid-body.

The transversal sections are orientated as $\mathrm{A}$.

Abbreviations: $\mathrm{d}=$ dorsal side; de : deirid ; $\mathrm{g}=$ left side.

Scales: A-C, $30 \mu \mathrm{m}$; D-F, $50 \mu \mathrm{m}$; G, H, $100 \mu \mathrm{m}$. 

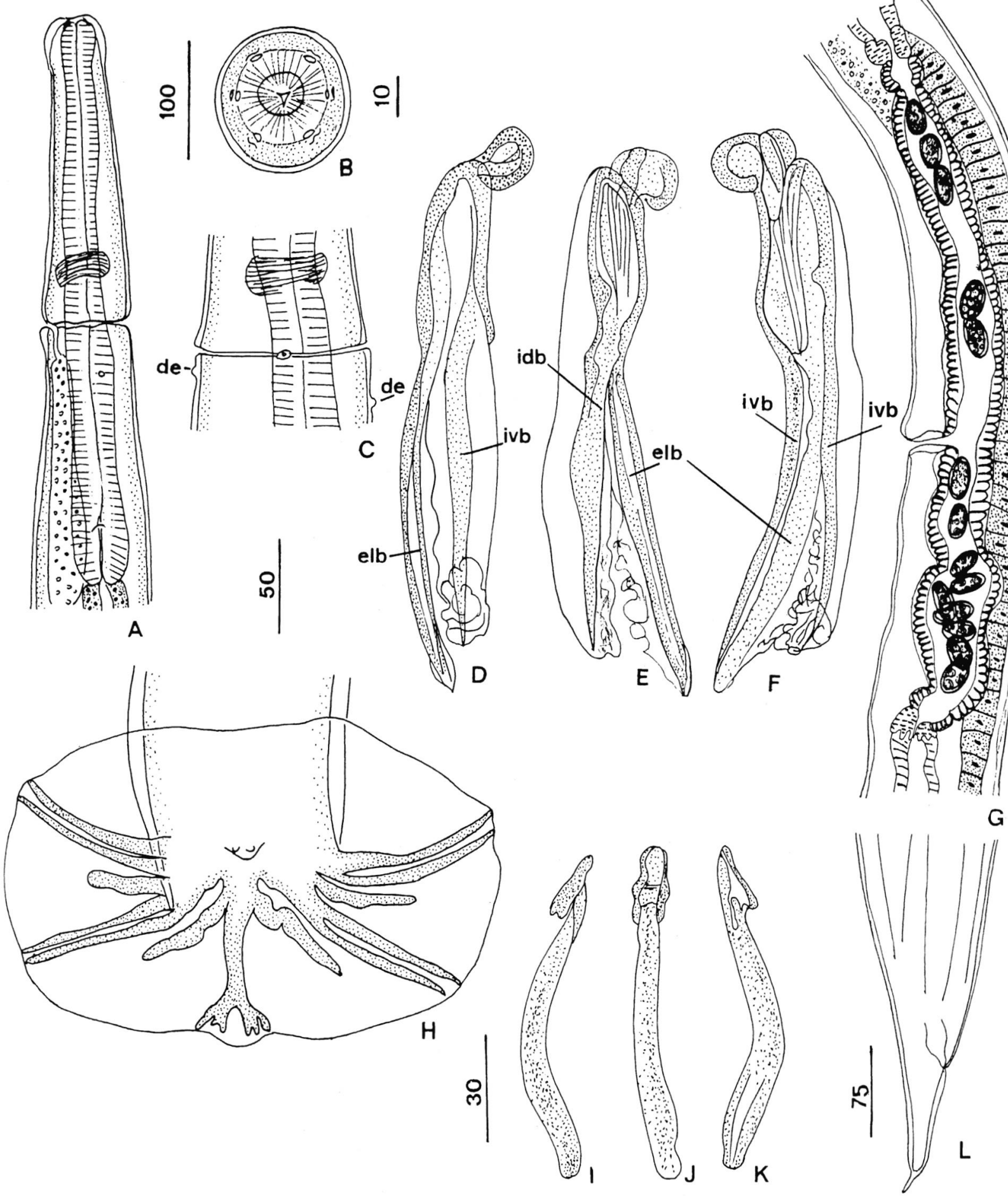

Fig. 2. - Molineus torulosus (Molin, 1861) in Cebus apella. A, male, anterior extremity, ventral view. B, male, head, apical view. C, male, detail of the furrow, the exretory pore and the deirids, ventral view. D-F, male, right spicule, D, ventral view, E, dorsal view, F, internolateral view. G, female, ovejector, left lateral view. $\mathrm{H}$, male, caudal bursa, ventral view. I-K, gubernaculum, I, right lateral view, J, ventral view, $\mathrm{K}$, left lateral view. L, female, tail, right lateral view.

Abbreviations: de = deirid; elb: externo-lateral branch; idb: interno-dorsal branch; ivb: interno-ventral branch.

Scales: A, $100 \mu \mathrm{m}$; B, $10 \mu \mathrm{m}$; C , H , $50 \mu \mathrm{m}$; D-F, I-K, $30 \mu \mathrm{m} ; \mathrm{G}, 150 \mu \mathrm{m} ; \mathrm{L}, 75 \mu \mathrm{m}$. 
Didelphic: vulva at 2.5 (2.2-2.9) from caudal extremity Vagina vera: 46 (42-50) long, divided vestibule into two equivalent parts; vestibule, $1.3(1.2-1.4) \mathrm{mm}$ long; anterior sphincter and infundibulum 46 (35-65) and 36 (20-45) long, respectively; posterior sphincter and infundibulum 45 (35-60) and 36 (20-45) long, respectively (Fig. 2G). Anterior uterine branch 1.6 (1.4-1.8) Posterior uterine branch 1.5 (1.3-1.7) long. Each uterine branch with 50 to 100 eggs, morula stage 64 (5875) long by 34 (26-40) wide. Tail 129 (110-160) long with caudal spine 20 (15-28) long) (Fig. 2L).

\section{Histology}

Grossly, the cystic formations were of variable size, the greatest measuring $0.7 \mathrm{~cm}$ in diameter, developed alongside the external aspect of the small intestine. Histologically, the cysts developed in the outermost part of the intestinal wall, carved in the muscular layer and uplifting the intestinal serosa (Fig. 3). In some areas, the cysts communicated with the intestinal lumen by a small channel. The cystic lumen presented an irregular contour. It was lined with inflammatory tissue made up of numerous inflammatory cells: neutrophil leukocytes interspersed with lymphocytes and histiocytes (Figs 3, 4). Some cysts contained adult worms entsheathed in fibrinous material leading to Splendor Hoepli phenomenon (Fig. 5). According to the predominant inflammatory cells in the wall, there were three types of cysts: $\left.1^{\circ}\right)$ Newly-formed cysts containing predominantly neutrophils leukocytes. The cystic lumen was centered by a dozen intertwined worms. $2^{\circ}$ ) Advanced cysts containing fewer neutrophil leukocytes, more monocytes and lymphocytes (Fig. 6). Adult worms were less numerous. Fibrotic strands starting at the periphery, penetrated the cyst lumen (Fig. 7). $3^{\circ}$ ) Chronic old cysts having a lumen almost completely sealed by fibrotic tissue and devoid of worms (Fig. 8). In the mesentery, some veins displayed fibrinous thrombosis clogging the lumen with infiltration of inflammatory cells in the surrounding adipose tissue (Fig. 9).

\section{DISCUSSION}

F Tour species belonging to the genus Molineus were parasites of Neotropical primates: M. elegans (Travassos, 1921), of Saimiri sciurea from Brazil; M. midas Durette-Desset \& Corvione, 1998, of Sanguinus midas from French Guyana and M. torulosus (Molin, 1861) of Cebus capucinus from Brazil were found in the small intestine. M. vexillarius Dunn, 1961, a parasite of Tamarinus nigricollis from Peru was found in the stomach.

The nematodes described below can easily be identified with Molineus torulosus sensu Molin, 1861 nec
Cameron, 1923, redescribed by Travassos in 1937: the caudal bursa lacks spiny lateral lobes; the length of rays 4 is about $40 \%$ of that of rays 3 versus more than $55 \%$ in the other three species; rays 8 are longer than the dorsal ray. In addition, $M$. torulosus is the sole species to have a location in the cysts. The host-spectrum is made up of only species of Cebus distributed throughout the septentrional part of South America: Cebus capucinus from Brazil, region not precised (Molin, 1861), Mato grosso (Travassos, 1937), S. Joâo, Mato Grosso, Rio de Janeiro (Rego \& Schaëffer, 1987); Cebus apella from Brazil, Mato Grosso (Travassos, 1937), Salobra, Mato grosso, Linhaeres, Esperito Sancto (Rego \& Schaëffer, 1987) French Guyana (this work); Cebus apella from Argentina, Chaco Boreal (Mazza, Parodi \& Brian, 1930 ; Cebus olivaceus from French Guyana (this work); Cebus sp. from Brasil, Manaus, Amazonas. Brack et al. (1973), Brack (1976) studied the lesions of M. torulosus in Cebus apella but they did not specify the geographical origin of the monkeys.

From the pathological standpoint, the morphological patterns of the cysts were very similar to those previously described by other authors in Capucin monkeys (Schwartz, 1928, Brack, 1976, Rego \& Schaëffer, 1987). These cysts were deeply carved in the outermost part of the muscular layer and the serosa of the small intestine. Identical findings were also recorded in gazelles with Gazellostrongylus lerouxi, Yeh, 1956 (Khalil \& Ingram, 1981).

In our opinion, the turn out of the cyst walls corresponded to the three-staged inflammatory reaction: acute, sub-acute and chronic. The larvae penetrated the intestinal wall and induced cyst formation alongside the external part of the muscular layer or at the junction of the muscular layer and the serosa. These cavities communicated with the intestinal lumen through a narrow channel. The mature larvae became adult worms, copulated and laid eggs. Adult worms were assumed to reside permanently in the cyst lumen as their presence had never been evidenced in the intestinal lumen. Only laid eggs were released in the intestinal lumen through the channel whose diameter might be too small to let the adult worms pass through. Free eggs hatched and promoted the developmental cycle. Splendore Hoepli phenomenon evidenced in cysts containing worms was a camouflage mechanism of the parasites against the host immune reaction. This phenomenon was not specific to Molineus as it had also been noted in other parasitic diseases. (Vuong et al., 1993, 1994, 1996). With time, the inflammatory reaction waned and the lesion underwent scarring. The cystic wall became less cellular and more fibrotic. Mature worms degenerated and died when the connective tissue sealed the cystic lumen. Theses changes were similar to the findings noted in gazelles (Khalil 


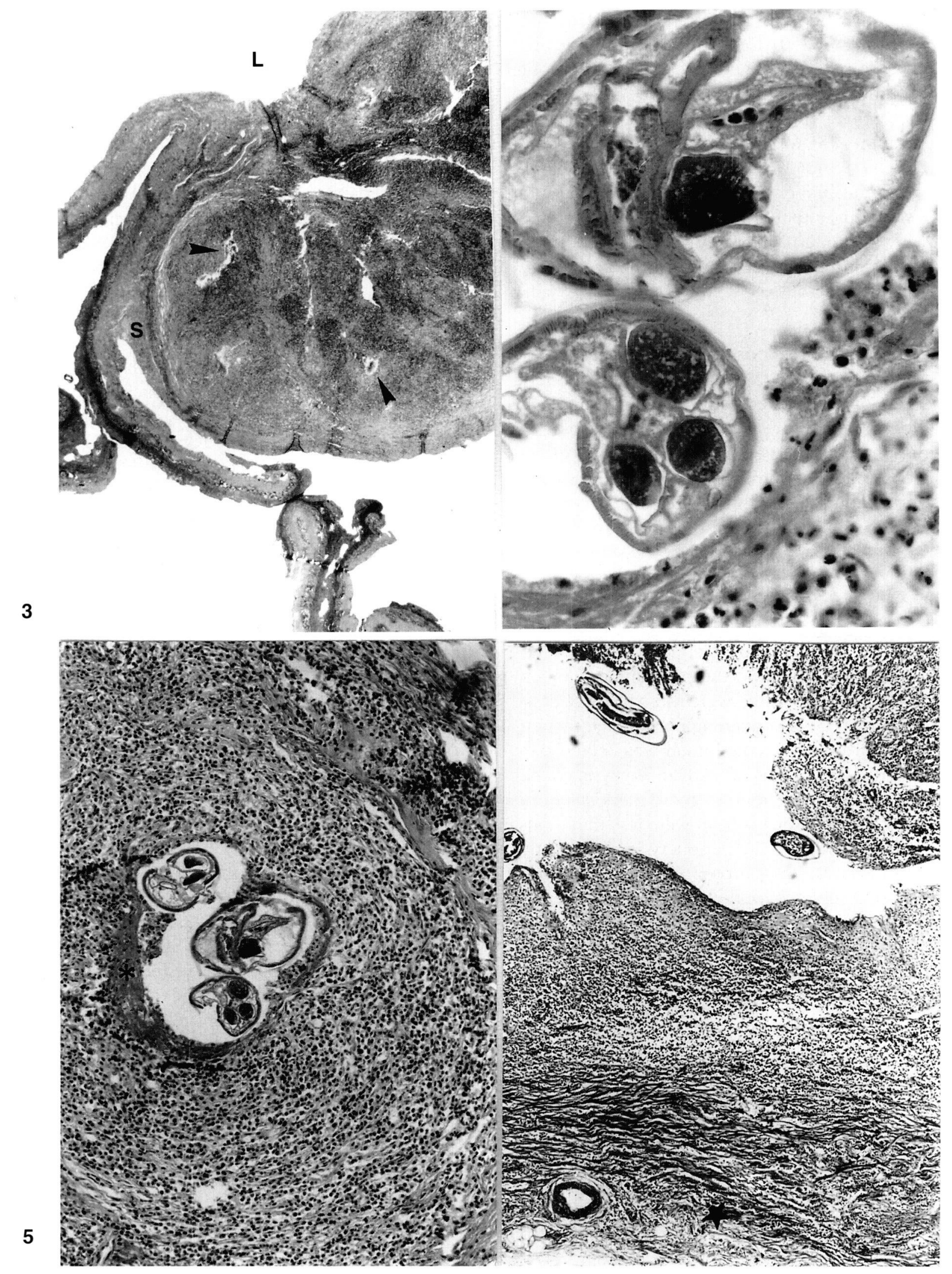

Fig. 3. - Cyst carved alongside the external part of the intestinal wall. Arrow head: adult worms. L: intestinal lumen. S: serosa. Haematoxylin-Eosin-Saffron (HES).

Fig. 4. - Adult worms surrounded by neutrophil leukocytes. HES.

Fig. 5. - Ensheathed adult worms in fibrinous debris (asterisk) among the inflammatory infiltrate containing neutrophil leukocytes. HES.

Fig. 6. - Advanced cysts with starting fibrosis (star) developed at the periphery. HES. 

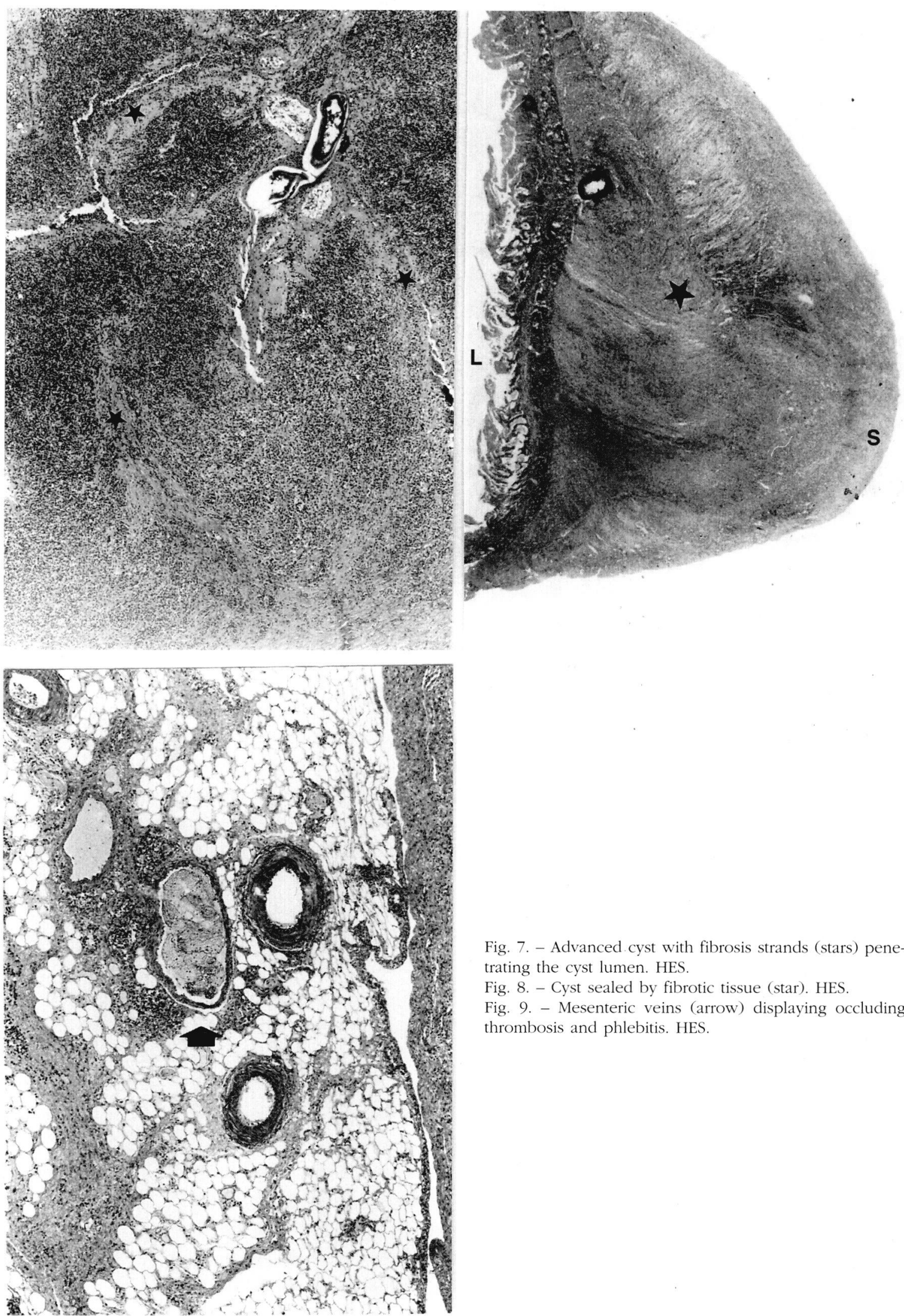

Fig. 7. - Advanced cyst with fibrosis strands (stars) penetrating the cyst lumen. HES.

Fig. 8. - Cyst sealed by fibrotic tissue (star). HES.

Fig. 9. - Mesenteric veins (arrow) displaying occluding thrombosis and phlebitis. HES. 
\& Ingram, 1981). Vascular changes may also occur around the cysts or in the mesentery. The eggs accidentaly laid inside the capillaries and the veins surrounding the cysts could probably induce thrombophlebitis observed in mesenteric veins.

\section{AKNOWLEDGEMENTS}

7 he authors are grateful to the ethnologists Drs. Françoise Grenand (CNRS) and Pierre Grenand (IRD), Guyana Indian specialists for their help in the field.

\section{REFERENCES}

BRACK M. Pathologisch-Anatomische des befalls mit Molineus torulosus oder Filaroides cebus beim Kapuziner (Cebus apella). In: Ippen R. and Schröder H.D. (eds), Erkrankungen der Zootiere, Verhandlungsbericht des XVIII Internationalen Symposium über die Erkrankungen der Zootiere, 16-20 June 1976, Innsbruck, Berlin, Germany (DDR). Akademie-Verlag, 1976, 213-218.

Brack M., Myers B.J. \& KunTz R.E. Pathogenic properties of Molineus torulosus in capuchin monkeys, Cebus apella. Laboratory Animal Science, 1973, 23, 360-365.

CAmEron T.W.M. Studies on two genera and some little known species of the nematode family Trichostrongylidae, Leiper. Journal of Helminthology, 1923, 1, 71-96.

DunN F.L. Molineus vexillarius sp. n. (Nematoda: Trichostrongylidae) from a Peruvian primate, Tamarinus nigricollis (Spix, 1823). Journal of Parasitology, 1961, 47, 953956.

Durette-Desset M.-C. Trichostrongyloid nematodes and their vertebrate hosts: Reconstruction of the phylogeny of a parasitic group. Advances in Parasitology, 1985, 24, 239306

Durette-Desset M.-C. \& Chabaud A.G. Nouvel essai de classification des Nématodes Trichostrongyloidea. Annales de Parasitologie bumaine et comparée, 1981, 56, 297-312.

Durette-Desset M.-C. \& Chabaud A.G. Note sur la nomenclature supra-familiale des Strongylida. Annales de Parasitologie Humaine et Comparée, 1995, 68, 111-112.

Durette-Desset M.-C. \& Corvione M. Une nouvelle espèce de Molineus (Nematoda, Trichostrongylina, Molineoidea) parasite d'un Primate sud-américain. Zoosystema, 1998, 20, 445-450.

KhaliL L.F. \& Ingram P.L. Gazellostrongylus lerouxi Yeh, 1956 from Thomson's and Grant's Gazelles in Kenya. In: Wildlife Diseases of the Pacific Basin and other Countries. Proceedings of the $4^{\text {th }}$ International Conference of Wildife Disease Association. Sydney, Australia, August 25-28. Edited by Fowler M.E., 1981, pp. 132-136.

Mazza S., Parodi S.E. \& Brian B.B. Estrongylosis intestinal y pulmonar en el Cebus libidinosus. Patologia, 1930, 2, 2231.
Molin R. Il Sottordine degli acrofalli ordinato scientificamente secondo i risultamenti delle indagini anatomiche ed embriogeniche.Memorie del Istituto Veneto di Science lettere ed arti. Venezia, 1861, 9, 427-633 (non consulté).

REgo A.A \& SCHÄEFFER G. Molineus torulosus (Molin, 1861) (Nematoda; Trichostrongyloidea) patogenia em Cebus (Primata). Arquivos Fluminenses de Medicina Veterinaria, 1987, 2, 113-115.

SCHWARTZ B. A new species of Trichostrongylid worm of the genus Cooperia from the Carabao in the Phippine Islands, with a review of the genus. Proceedings of the United States National Museum, 1928, 74, 1-5.

Travassos L. Nematodeos novos. Brazil Medico, 1921, 35 , 367-368.

Travassos L. Revisao da familia Trichostrongylidae Leiper, 1912. Monographias do Instituto Oswaldo Cruz, 1937, 1, $1-512$.

Vuong P.N., Bayssade-Dufour Ch., Albaret J.L. \& Farhati K. Histopathological observations in new and classical models of experimental Schistosoma haematobium infections. Tropical Medicine International Health, 1996, 1, 348-358.

VuOng P.N., Spratt D., Wanji S., Aimard L. \& Bain O. Onchocerca-like lesions induced by the filaria Cercopithifilaria johnstoni in its natural hosts and in the laboratory Annales de Parasitologie humaine et comparée, 1993, 68, 176-181.

VuOng P.N., Wanji S, Prod'hon J. \& Bain O. Lésions cutanées et nodules sous-cutanés causés par les diverses onchocerques chez les bovins africains. Revue de l'Élevage Médical et Vétérinaire des Pays tropicaux, 1994, 47, 4751.

Wilson E. \& ReEder D.M. Mammal Species of the World. A taxonomic and geographic reference. Smithsonian Institution Press, Washington, London, 1993, 1-1207.

YEH I.S. On a collection of helminths from Thomson's gazelle, Gazella thomsoni from Tanganyika. Journal of Helminthology, 1956, 29, 203-228.

Reçu le 6 octobre 2000 Accepté le 13 janvier 2001 